\title{
Drivers and Barriers Leading to a Successful Paradigm Shift toward Regenerative Neighborhoods
}

\author{
Edeltraud Haselsteiner ${ }^{1, *}$, Blerta Vula Rizvanolli ${ }^{2}$, Paola Villoria Sáez ${ }^{3 \oplus}$ and Odysseas Kontovourkis ${ }^{4}$ \\ 1 Urbanity—Architecture, Art, Culture and Literature, 1140 Vienna, Austria \\ 2 Department of Architecture and Spatial Planning, UBT College, 10000 Pristina, Kosovo; \\ blerta.vula@ubt-uni.net \\ 3 TEMA Research Group, Escuela Técnica Superior de Edificación, Universidad Politécnica de Madrid, \\ 28040 Madrid, Spain; paola.villoria@upm.es \\ 4 Department of Architecture, University of Cyprus, Nicosia 1678, Cyprus; kontovourkis.odysseas@ucy.ac.cy \\ * Correspondence: edeltraud.haselsteiner@aon.at
}

Citation: Haselsteiner, E.; Rizvanolli, B.V.; Villoria Sáez, P.; Kontovourkis, O. Drivers and Barriers Leading to a Successful Paradigm Shift toward Regenerative Neighborhoods. Sustainability 2021, 13, 5179. https:// doi.org/10.3390/su13095179

Academic Editors: András Reith and Clarice Bleil de Souza

Received: 11 March 2021

Accepted: 29 April 2021

Published: 6 May 2021

Publisher's Note: MDPI stays neutral with regard to jurisdictional claims in published maps and institutional affiliations.

Copyright: (c) 2021 by the authors. Licensee MDPI, Basel, Switzerland. This article is an open access article distributed under the terms and conditions of the Creative Commons Attribution (CC BY) license (https:// creativecommons.org/licenses/by/ $4.0 /)$.

\begin{abstract}
Regenerative sustainability is gaining great attention as an essential concept for a transformative process, a re-designed mindset shifting from the narrowed focus of considering particular aspects such as energy efficiency, renewable materials, or sustainable technology towards the creation of a self-regenerating social and ecological system. Apart from being a vision of the future, regenerative sustainability has already been implemented successfully in individual projects, plans, and extensive strategies. The goals of this research are (1) to set up the conceptual framework for regenerative sustainability principles in the built environment; (2) to investigate and identify the drivers and barriers faced during the implementation of regenerative principles in the built environment; and (3) to identify gaps in the paradigm shift towards regenerative districts and macro-level projects. A multi-stage methodology was implemented. First, an in-depth literature review was conducted aiming to understand regenerative sustainability state of the art and define the key principles. Then, quantitative data analysis was conducted aiming to identify drivers and barriers of regenerative implementation in buildings following by semi-structured interviews with the representatives of regenerative buildings or districts. The step-by-step methodology resulted in the identified drivers of applying the regenerative principles, which are available financial incentives; marketing and sales benefits; improved companies/investors market image and competitive market advantage; reduced building lifecycle costs/effective use of energy and resources; enhancement buildings' users' well-being; and receiving building certification. The main barriers identified were lack of knowledge and experience working with regenerative materials and technologies by employees, consultants, and construction companies and usage of the available tools that enable such constructions; overall stakeholders' culture and their resistance to changing their mindset toward a regenerative approach; inadequacy of national and international standards and legislation to address regenerative policies; and increased construction cost and time and lack of financial incentives. Ultimately, during the broad examination of the case studies, regenerative qualities served as a valuable insight to understand barriers and drivers at neighborhood and macro levels.
\end{abstract}

Keywords: regenerative sustainability; building certification; self-regenerating eco-cycles; socioecological system; innovative technologies; social equity; well-being; circular economy; sustainable development goals (SDGs)

\section{Introduction}

Ambitious global climate protection targets were agreed on for the first time in 2015 with the Paris Agreement. The declared goals focus on keeping the global average temperature well below $2{ }^{\circ} \mathrm{C}$ compared to pre-industrial values, as well as on undertaking further efforts to limit it further to $1.5{ }^{\circ} \mathrm{C}$, which means a clear change in the direction of more climate protection. There is growing consensus that mitigating climate change 
requires urgent reductions in emissions in all economic sectors. The construction sector is responsible for a third of greenhouse gas emissions worldwide [1]. This means that in the construction industry, urgent decarbonization measures are required to contribute to achieving the climate goals by significantly reducing emissions.

To meet these challenges, a rethinking from a narrow focus on the consideration of individual aspects such as energy efficiency, renewable materials, or sustainable technology toward the creation of a self-regenerating social and ecological system is required [2-4]. Under the terms of "regenerative sustainability" and "regenerative design", concepts and standards are promoted which not only demand more stringent goals concerning their impact on the environment $[5,6]$, but also a change from a fragmented approach to one overall systemic consideration of the ecological system [4]. The first use of the term "regenerative design" is traced back to the landscape architect John Tillmann Lyle, who in 1994 presented a model of a "collaborative interdisciplinary design process" [7]. Lyle argued against degenerative linear input-output models and suggested a "regenerative cycle model" as an alternative. Based on twelve theoretical and practical principles, essential resources of daily life such as housing, food, water, or waste should be kept in a regenerative cyclical process of energy and material, and thus self-regenerating eco-cycles should be able to restore themselves in the built environment [7]. The idea of considering the built environment instead of looking to a single building and its components itself has been promoted by several authors [8-11], who recommended a holistic approach instead of a dispatched concepts approach. Concentrating only on building energy consumption or carbon emission would risk shifting the buildings' environmental impact from one factor to the other; that is why regenerative principles take into account the built environment as a whole.

Regenerative sustainability, therefore, aims to maintain, restore, and regenerate a healthy socio-ecological system. At the level of political action, this broader approach of a holistic view of the ecosystem is expanded in the United Nations Sustainable Development Goals (SDGs) about social aspects and a people-centered focus [12]. The 17 SDGs encompass economic, ecological, and social aspects, with combating poverty and reducing inequalities and injustices having a special priority alongside climate protection measures. All UN member countries are called upon to implement these goals in national development plans and thus the common vision by 2030. The effects of climate change affect people with varying degrees of severity and thus increasingly widen an already existing social and economic gap between countries in the Global South and countries in the Global North, but similarly within narrow geographical boundaries between groups with different vulnerabilities $[13,14]$.

\subsection{Regenerative Sustainability in the Context of Sustainable Building Certifications}

The interweaving between ecological, social, and economic goals, as presented in the SDGs with a clear focus on social challenges and distributive justice, is at least partially reflected in the broader approach of regenerative design concepts. Regenerative sustainability questions the "inadequate mechanistic worldview" with its sustainability discourse linked to technological innovations and stands for further development and a paradigmatic change in the consideration of sustainability [15-17]. The focus is on adaptation, resilience, and regeneration, as well as on "ecological worldview". This world view is expressed in the application of nature-based solutions, designs, and planning, which consider humans as an integral part of nature, as well as a specific consideration of regional and cultural differences of the place [3]. The latter in particular, the emphasis on the "place" and the respect for the specific socio-ecological interaction between people and place, is an essential distinguishing feature in contrast to the "green design" approach [18].

The term "Green Building" (GB) was mainly developed as a marketing tool and essentially describes buildings with increased requirements in terms of energy efficiency, the use of renewable energies, and other defined sustainability criteria. The Green Building label is based on various building certificates in which sustainability parameters are defined and 
assessed accordingly. Over the past two decades, the development of building certification standards has experienced rapid growth. Today, more than 600 different buildings and material certificates are in use around the world $[19,20]$. This number is still increasing and is being established into a growing market segment in the building sector. In addition to internationally recognized and applied certification programs such as BREEAM, LEED, or DGNB, national or institutional assessment schemes are constantly being added. The latter is primarily intended to support national regulations or institutional strategies in pursuing sustainability goals. Moreover, building certification also has significant marketing effects in the quantitative and qualitative approach which enables extensive comparison.

Comparison of the different rating systems displays the differences in the priority of goal pursuit. The building certification programs that have been on the market for 20 years or more (BREEAM 1990), the so-called "Green Building certificates" (BREEAM, LEED, DGNB), focus mainly on buildings' environmental data, particularly on the energy performance of the buildings $[19,20]$. Such a narrowed focus of separated aspects of sustainability has also been critically examined in many cases $[20,21]$. While evaluation criteria such as water, energy, material, or indoor climate can be found in almost all Green Building certificates, aspects such as "climatic responsive design", "advanced green efforts", or "neighborhood impacts" rank at the bottom of the list [22]. Moreover, social criteria are rarely explicitly stated as an indicator of green building design, their implementation is only given low weighting due to the low number of points that can be achieved [23], and they can only be found in neighborhood manuals and not in building certification standards [24].

Hence, today several alternative rating systems are used which focus more on the social dimension of sustainability, such as health and well-being or a contribution to society, than simply buildings' environmental data [5]. Living Building Challenge (ILFI-LBC), One Plant Living, WELL, or Cradle 2 Cradle (C2C) are just a few of the regenerative examples of certification systems.

\subsection{Drivers and Barriers for a Regenerative Construction}

Despite the drivers that affect the substantial growth of buildings and built environment cases that perform regenerative principles and aim to reach certification, the process still encounters basic barriers that increase the complexity of their large-scale implementation. Both drivers and barriers abbreviate equivalent qualities which are either motivated by social-environmental causes, political-legal circumstances, or economic factors. From the built environment perspective, regeneration and restoration are dissolved as reuse/repair/refurbishment/renewal/remanufacture/maintenance/upgrade/recycle [25], which are further applied in three different levels: macro level—cities and urban territories; meso level—focusing on single buildings; and micro level—emphasis on the construction materials [17]. In several cases, it has been shown that barriers are broader and more complicated to overcome compared to the motives that drive the application of regenerative principles, which is why the study cases are limited to micro and meso level [17].

The range of identified barriers for a regenerative construction process varies between five main clusters, namely, knowledge, culture, policy, leadership, and finance [11,26,27]. These are further expanded in several in-depth domains addressing the lack of employees' and consultant's knowledge and experience on sustainable and regenerative construction [19-22]; culture in its broad range-national culture, geographical culture, market culture, organizational culture, business culture, and energy culture-which deals with the limitation of the multi-disciplinary approach of built environment's stakeholders toward overall behavioral changes [28-30]; the complexity of legislation, regulatory and policy transformation, and adaptation which decelerate the sustainable construction boost on a larger scale [11,28-33]; the lack of initiatives to re-invent the management and leadership that embrace environmentally friendly decision-making [11,27-33]; and most importantly the financial barriers-sufficient public incentives that promote regenerative construction, increased overall and hidden construction costs, and the risk of uncertainty [11,27-33]. 
Moreover, it is empirically evidenced that the implementation of certification standards has been considered to the same extent an economical motivator and a financial inhibitor $[5,34,35]$. Government regulations and policies, incentive schemes, marketing benefits, competitive advantages, reduced building lifecycle costs, corporate social responsibility, and corporate image are only a few of the drivers [36], while the list of barriers varies from country to country, but in general, it remains within the five main clusters specified above.

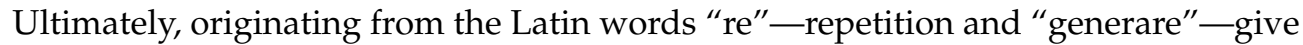
birth/generate, the regenerative sustainability notion is shifting from a niche conversation into the main subject in the built environment. Its implementation is motivated by several factors, but different barriers are pulling back its mass application. Whereas there are many successful examples of implementing the regenerative sustainability at meso and micro levels, the challenge of revitalizing socio-economic regeneration is especially notable in larger-scale territories that aim to achieve sustainability and circularity goals. In this case, several additional barriers are faced such as awareness, political, economic [37], legislative [38], governance system [39], collaboration among built environment stakeholders [40], and most of all the cultural approach [41]. Furthermore, considering the complexity of the application of regenerative sustainability processes in large-scale-built environments and knowing the number of stakeholders involved, overcoming the technological and regulatory barriers would not be sufficient without an essential upgrade of business models and crucial elevation of stakeholders' behaviors and attitudes [26].

\subsection{Scope and Research Strategy}

The goals of this study are (1) to set up the conceptual framework for regenerative sustainability principles in the built environment; (2) to investigate and identify the drivers and barriers faced during the implementation of regenerative principles in the built environment; and (3) to identify gaps in the paradigm shift towards regenerative districts and macro-level projects. Based on a comprehensive literature review, criteria and parameters of regenerative principles were defined in a first step, which provided the conceptual framework for further empirical studies. Further, a detailed analysis was conducted of the drivers and barriers identified during the implementation of regenerative sustainability in the built environment, mostly in micro- and meso-level projects, undertaken through a snowball sampling questionnaire among European-wide built-environment stakeholders. Recognized gaps from the literature and data analysis from the questionnaires were contrasted and compared with the results of the in-depth interviews with carefully chosen representatives of regenerative buildings and neighborhoods in various European countries, which have been examined to comprehend the empirical review of the case studies. Finally, the identified motivators and challenges of individual case studies (micro or meso level) were explored contrasting larger-scale projects (macro level) aiming to perceive the paradigm shift toward regenerative neighborhoods.

\section{Materials and Methods}

The research method was based on a thematically well-founded literature review in combination with quantitative and qualitative approaches. Figure 1 shows the different research steps conducted (marked in bold) as well as the research methods applied in each step (in brackets) and the expected results obtained (highlighted in green). 


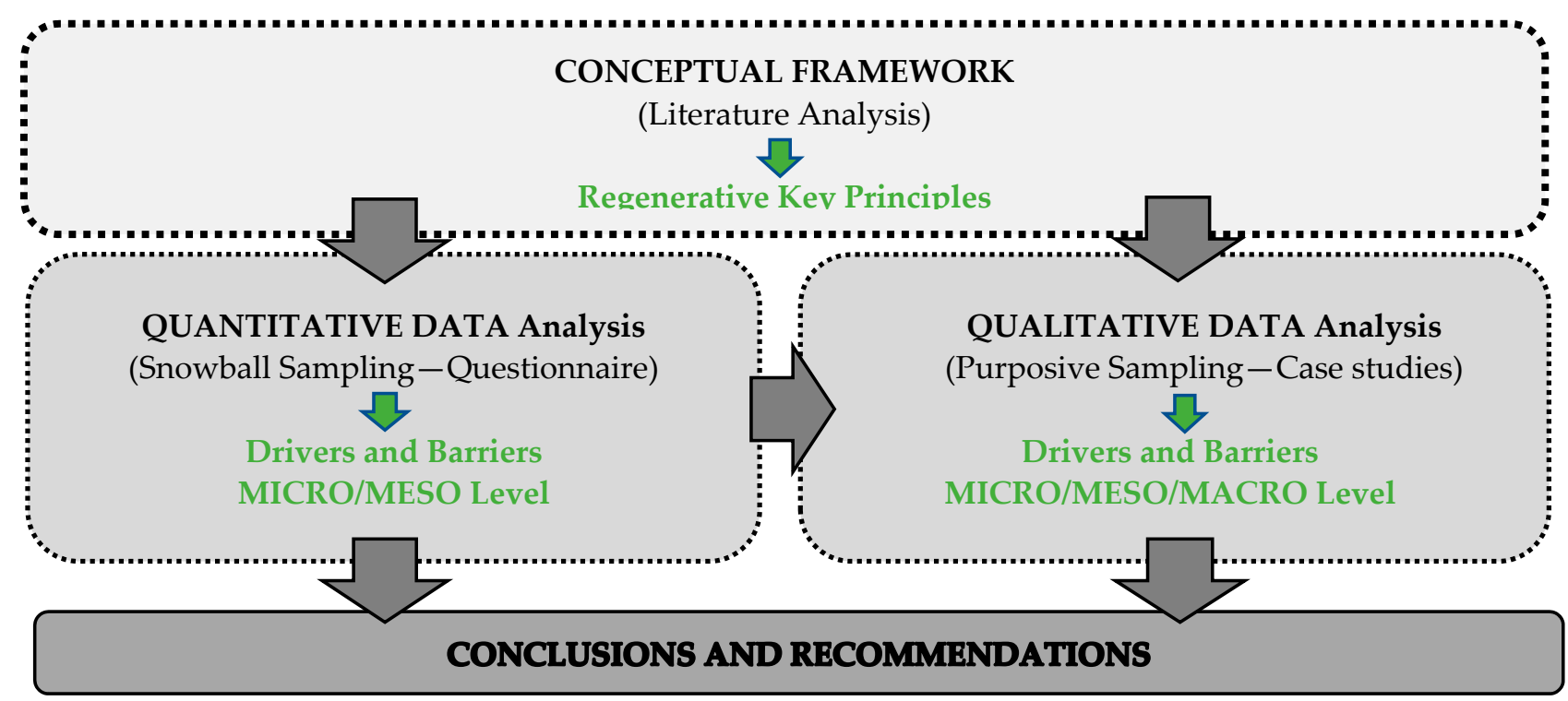

Figure 1. Methodological framework.

\subsection{Conceptual Framework}

First, an in-depth literature review was conducted aiming to understand the state of the art and define the key principles of regenerative sustainability. The literature search started with a systematic web-based search of research focused on regenerative sustainability. Moreover, the "reference by reference" method was used to find relevant publications. As a first step, papers were analyzed that had already carried out a comprehensive literature study on the subject of regenerative design principles in the built environment [3,4,42-44].

Additionally, a thorough review was conducted to analyze how commonly used certification systems address regenerative sustainability principles. For this, a table was developed analyzing seven certification systems, namely: BREEAM Building, LEED, DGNB, ILFI-LBC, WELL Build, One Planet Living, and Cradle 2 Cradle and their relation with the twelve principles of regenerative sustainability identified in the first phase of this methodological step: (1) nature/eco-system; (2) energy; (3) carbon emission; (4) water management; (5) regenerative materials; (6) waste management; (7) health and well-being; (8) social equity; (9) economy; (10) culture and community; (11) education/inspiration; and (12) mobility.

\subsection{Quantitative Data Analysis, Snowball Sampling}

The initial authors' work, undertaken within COST RESTORE [45], was based on quantitative data analysis through a multi-section survey that aimed to understand the level of implementation of regenerative construction within different countries in Europe and to identify challenges and difficulties of implementation. Intentionally, an exponential non-discriminative snowballing method $[46,47]$ was used as a sampling strategy, with the perspective of facilitating the RESTORE's expertise to identify potential respondents. This sampling strategy had as an initial reference the RESTORE network of 150 professionals from 40 different European countries, whose expertise included fields such as architecture, urban planning, bioclimatic design, landscape design, human geography, etc. This chainreferral method was chosen aiming to enable the authors to further deepen the research with purposive or selective sampling to understand particular regenerative principles' application in the construction industry.

The survey was divided into three main sections, which included close-ended and open-ended questions on materials, technologies, and tools (MTT) that different respondents used during different stages of building construction (Supplementary: Questionnaire A). This survey was delivered to more than 120 professionals-architects and engineers-as 
well as other built environment stakeholders, receiving 64 valid responses. Respondents were mainly architects and engineers followed by project managers and investors. The respondents were asked to indicate to what extent they use MTT that ensures and facilitates regenerative buildings.

- Materials: Innovative and cutting-edge materials in the construction industry, including materials changing their properties depending on the environment (phase-change materials), self-healing materials, or materials improving the indoor/outdoor air quality.

- Technologies: Innovative and cutting-edge technologies with very few implementations currently in the construction industry, such as the Internet of Things (IoT), augmented reality, drones, 3D printing for cement-based/clay-based materials, etc.

- Tools: Construction standards (ISO, EUROCODES, DIN, BSI, etc.) or Sustainable Building Certification Systems (LEED, BREAM, DGNB, etc.)

Respondents had to answer on a 5-option scale of "I don't implement it at all"; "10-20\%"; "20-50\%"; "50-90\%"; or "I always implement them". Grading on a 5-point scale has commonly been used in previous research works [48,49]. It was also very important to understand the type of buildings for which they used regenerative MTT, distinguishing between newly built constructions and rehabilitation projects. In this sense, respondents were asked to indicate which type of buildings they implement MTT in: residential, commercial, or iconic/singular buildings. Iconic architecture is defined as buildings and spaces that are famous for professional architects and/or the public at large and have special symbolic/aesthetic significance attached to them [50].

Finally, respondents were required to identify the main barriers faced while implementing regenerative sustainability MTTs. In this case, respondents were given a list of possible answers, but they could also mention other barriers that were not included in the list offered. This allowed the identification of other aspects that were not included in the questionnaire.

Based on the data from this survey, new quantitative data analyses were carried out for this article, in particular, to identify barriers in the implementation of regenerative construction within different countries in Europe.

\subsection{Qualitative Data Analysis, Purposive Sampling-Case Studies}

Recognizing gaps and the lack of the information required to identify the actual drivers and barriers that enhance the implementation of regenerative sustainability in the initial quantitative data analysis approach, an additional qualitative approach was carried out, which was based on semi-structured interviews with the representatives of regenerative buildings or districts built in Europe. The semi-structured interviews aimed to understand what the main drivers and barriers were that affected their decision-making process for implementing a regenerative building or neighborhood, and thus, covering barriers and drivers for micro, meso, and macro scale projects.

Knowing that regenerative case studies are not common in the construction industry, the sampling selection method used to identify them was purposive sampling. This strategy has been well defined by Patton [46] — "The logic and power of qualitative purposeful sampling derive from the emphasis on an in-depth understanding of specific cases: information-rich cases. Information-rich cases are those from which one can learn a great deal about issues of central importance to the purpose of the research; thus the term purposeful sampling."

The sample selection for this research has been referred to in the databases of different certification standards such as LEED, DGNB, WELL, LBC, and Cradle 2 Cradle. Multistep classification was applied to identify the necessary targeted samples. The primary and most important classification included the highest-ranked buildings in one of the above-mentioned certification standards; during the second classification, the individual buildings study cases were distinguished from the neighborhood or community cases aiming to have combined representation; and finally, the cases were selected in a way 
that covered all four European regions (Western, Eastern, Southern, and Northern Europe) based on UN classification [51].

Project details and stakeholders' / decision-makers' contact information (i.e., the owner, investor, developer, architect, project manager, auditor/assessor, external energy advisor, external sustainability advisor, etc.) for 13 selected case studies were obtained from the databases of the above-mentioned certification standards or the projects' website. Further, an invitation to conduct the interview was sent to the contact details gathered and a positive response from representatives of each case study was received.

The interview was divided into three different sections (Supplementary: Questionnaire B).

1. The first section aimed to gather general information about the respondents (i.e., country of origin and stakeholder's role in the project);

2. The second section aimed to understand how the twelve regenerative principles were implemented in the case study. This section included three close-ended multiplechoice questions (single response) with a ranking scale (low, medium, and high implementation) and one multiple choice (multiple response) question to gather information about the key agent who was significantly involved in the decision-making process of implementing the regenerative principles. The close-ended questions were used intentionally considering the wideness of the topic and the possibility of the respondent misunderstanding the question. In addition to all close-ended questions, an open-ended question was added as an opportunity for the respondents to further elaborate on the implementation process of the regenerative principles.

3. The third and last section of the interview aimed to gather general information and extract recommendations for easier implementation of regenerative sustainability principles in future projects. This section included four open-ended questions.

The interviews with representatives of the thirteen case studies who accepted the invitation were conducted in February 2021 and results were subsequently analyzed.

\section{Results}

3.1. Conceptual Framework—Regenerative Key Principles and Their Implementation in Sustainable Building Certifications

Since there are no clearly defined criteria for a regenerative design of the built environment so far, we derived them from the available literature, i.e., [7,52,53], based on "regenerative standards" [5], and finally, based on the 17 UN's sustainability goals, following the twelve principles as the basis for our concept of regenerative sustainability. These twelve principles reflect the original idea of John Tillmann Lyle [7], according to which sustainable development is based on a model of circular processes of the ecosystem, with the aim of mutually beneficial coevolution of the social and ecological system. Ecological regeneration on the one hand and regenerative social development on the other hand were concretized based on these principles and interpreted appropriately for application at the level of buildings, neighborhoods, or districts. Table 1 lists the regenerative principles and explains their application using specific examples. These are compared to the 17 UN's sustainability goals to show how these principles support or reflect these goals accordingly.

The purpose of this research was not weighing up a detailed analysis of different buildings' rating systems, rather, it was demonstrating the way that the rating systems have already accelerated during the implementation of regenerative aspects and thus, these are also increasingly recognized as "drivers". The seven sustainable building certification systems selected for this research analysis and comparison were BREEAM, LEED, and DGNB as Green Building Certificates; and ILFI-LBC, One Plant Living, WELL, and C2C particularly keen to ensure that regenerative principles take hold in the built environment. These rating systems were deliberately chosen due to their relevance for the European construction industry and their international distribution [20,22]. Table 2 shows an overview of the twelve regenerative principles and how these aspects are covered in "Green Building" (GB) or "regenerative" rating tools. 
Table 1. Regenerative Sustainability principles-overview.

\begin{tabular}{|c|c|c|}
\hline $\begin{array}{c}\text { Regenerative Principles: } \\
\text { Key Topics }\end{array}$ & $\begin{array}{l}\text { Description [2,7,52-54] (Examples on } \\
\text { Building/Neighborhood/District Level) }\end{array}$ & 17 Sustainable Development Goals (SDGs) \\
\hline $\begin{array}{l}\text { PLACE, NATURE } \\
\text { AND ECO-SYSTEM }\end{array}$ & $\begin{array}{l}\text { Place-based design approach to regenerate the } \\
\text { ecosystem and enable it to evolve in the future } \\
\text { (i.e., approaches departing from the } \\
\text { recognition that each place is a unique } \\
\text { dynamic entity, building interacting with green } \\
\text { neighborhood and environment, protect the } \\
\text { ecosystem, rebuild soil, adaptation to } \\
\text { bio/microclimate). }\end{array}$ & $\begin{array}{l}\text { 13. Climate Action: Take urgent action to } \\
\text { combat climate change and its impacts. } \\
\text { 15. Life on Land: Protect, restore, and promote } \\
\text { the sustainable use of terrestrial ecosystems, } \\
\text { sustainably manage forests, combat } \\
\text { desertification, and halt and reverse land } \\
\text { degradation and halt biodiversity loss. }\end{array}$ \\
\hline
\end{tabular}

Restorative and regenerative energy systems, effective use and sharing of energy, energy as part of a coherent restoration approach

ENERGY (i.e., energy as part of a coherent restoration approach aiming to increase the quality of the ecosystem, renewable, restorative, and regenerative energy systems, effective use and sharing, and energy storage).

Carbon-neutral/climate-positive approaches, carbon-reducing measures

CARBON (i.e., reduce building's carbon footprint, environmentally responsible sources, life cycle assessment).

Reduce "water footprint", preserve natural water cycles, water treatment, reuse, and access to clean drinking water

WATER (i.e., improved water supply and water management, net-positive water, rainwater harvesting).

Improve material and resource cycles, life cycle assessment, productive organic systems to MATERIAL AND conserve resources and maintain them for RESSOURCES future generations (i.e., healthy materials, transparent labeling, responsible use, and conservation).

Zero waste approach, design for disassembly,

WASTE deconstruction, and flexibility of use (i.e., cradle2cradle approach, upcycling, reuse, and recycling of materials and buildings).

Reconnect human with nature, enhance the quality of life and contribute to individual, community, and society health and well-being without exploiting other people, the

HEALTH AND

WELL-BEING environment, or future generations (i.e., apply the principles of salutogenesis and biophilia, access to healthy food, ensure air quality, daylight, comfort, and mindfulness).

Equality, empowerment, and participation of people and countries, fairness in allocating resources, inclusiveness, supporting vulnerable people

SOCIAL EQUITY (i.e., empowerment of women, older and young people, giving disadvantaged groups a voice, no threat associated with food production, globally responsible action in dealing with resources).
7. Affordable and Clean Energy: Ensure access to affordable, reliable, sustainable, and modern energy for all.

13. Climate Action: Take urgent action to combat climate change and its impacts.

6. Clean Water and Sanitation: Ensure availability and sustainable management of water and sanitation for all.

14. Life Below Water: Conserve and sustainably use the oceans, seas, and marine resources for sustainable development.

\section{Responsible Consumption and}

Production: Ensure sustainable consumption and production patterns.

\section{Responsible Consumption and}

Production: Ensure sustainable consumption and production patterns.
3. Good Health and Well-Being: Ensure healthy lives and promote well-being for all of all ages

1. No Poverty: End poverty in all its forms everywhere.

2. Zero Hunger: End hunger, achieve food security and improved nutrition, and promote sustainable agriculture.

5. Gender Equality: Achieve gender equality and empower all women and girls.

10. Reduce Inequalities: Reduce inequality within and among countries. 
Table 1. Cont.

\begin{tabular}{|c|c|c|}
\hline $\begin{array}{l}\text { Regenerative Principles: } \\
\text { Key Topics }\end{array}$ & $\begin{array}{l}\text { Description [2,7,52-54] (Examples on } \\
\text { Building/Neighborhood/District Level) }\end{array}$ & 17 Sustainable Development Goals (SDGs) \\
\hline ECONOMY & $\begin{array}{l}\text { Regenerative -, circular-, and sharing economy, } \\
\text { sustainable production and consumption, } \\
\text { collaborative, place-based economies at } \\
\text { multiple scales } \\
\text { (i.e., restorative enterprises, redesign business } \\
\text { models from selling products that create waste } \\
\text { to providing services in closed-loop models, } \\
\text { energy unions). }\end{array}$ & $\begin{array}{l}\text { 8. Decent Work and Economic Growth: } \\
\text { Promote sustained, inclusive, and sustainable } \\
\text { economic growth, full and productive } \\
\text { employment, and decent work for all. } \\
\text { 9. Industry, Innovation, and Infrastructure: } \\
\text { Build resilient infrastructure, promote } \\
\text { inclusive and sustainable industrialization, } \\
\text { and foster innovation. }\end{array}$ \\
\hline $\begin{array}{l}\text { CULTURE AND } \\
\text { COMMUNITY }\end{array}$ & $\begin{array}{l}\text { Address the social determinants of health, } \\
\text { foster social cohesion, community identity, and } \\
\text { empowerment, foster accessibility and } \\
\text { integration } \\
\text { (i.e., re-integrated lively heritage, } \\
\text { buildings/local heritage as a visual, social, } \\
\text { cultural, and economic catalyst for the } \\
\text { community, accessibility of cultural and } \\
\text { historical places, empowerment of rural } \\
\text { communities). }\end{array}$ & $\begin{array}{l}\text { 11. Sustainable Cities and Communities: } \\
\text { Make cities and human settlements inclusive, } \\
\text { safe, resilient, and sustainable } \\
\text { 16. Peace, Justice, and Strong Institutions: } \\
\text { Promote peaceful and inclusive societies for } \\
\text { sustainable development, provide access to } \\
\text { justice for all, and build effective, accountable, } \\
\text { and inclusive institutions at all levels. }\end{array}$ \\
\hline $\begin{array}{l}\text { EDUCATION AND } \\
\text { INSPIRATION }\end{array}$ & $\begin{array}{l}\text { Enable and encourage participation, } \\
\text { bottom-up cultures and initiatives, education } \\
\text { for eco-literacy, increase awareness } \\
\text { (i.e., encourage pioneer movements like } \\
\text { permaculture, urban gardening, } \\
\text { placemaking, etc., give a voice to different } \\
\text { sectors and interests of the society, continuous } \\
\text { learning and feedback, cooperation, } \\
\text { interaction, and interdisciplinary planning). }\end{array}$ & $\begin{array}{l}\text { 4. Quality Education: Ensure inclusive and } \\
\text { equitable quality education and promote } \\
\text { lifelong learning opportunities for all. } \\
\text { 17. Partnership for the Goals: Strengthen the } \\
\text { means of implementation and revitalize the } \\
\text { global partnership for sustainable } \\
\text { development. }\end{array}$ \\
\hline $\begin{array}{l}\text { ENVIRONMENT } \\
\text { AND MOBILITY }\end{array}$ & $\begin{array}{l}\text { Reduce } \mathrm{CO}_{2} \text { emissions caused by travel and } \\
\text { transport, encourage walking and cycling, } \\
\text { walkable cities, rural-urban balance } \\
\text { (i.e., reduce transport volumes at the building } \\
\text { site, encourage and enable carsharing, E-car } \\
\text { charging stations, bicycle parking spaces and } \\
\text { cycle paths, footpaths to schools, shops). }\end{array}$ & $\begin{array}{l}\text { 9. Industry, Innovation, and Infrastructure: } \\
\text { Build resilient infrastructure, promote } \\
\text { inclusive and sustainable industrialization, } \\
\text { and foster innovation. }\end{array}$ \\
\hline
\end{tabular}


Table 2. Regenerative sustainability principles implemented in sustainable building certifications.

\begin{tabular}{|c|c|c|c|c|c|c|c|}
\hline \multirow{2}{*}{$\begin{array}{l}12 \text { Regenerative } \\
\text { Principles }\end{array}$} & \multicolumn{3}{|c|}{$\begin{array}{c}\text { “Green Building” Rating Tools (= Focus on Energy Efficiency and } \\
\text { Technical Quality) }\end{array}$} & \multicolumn{4}{|c|}{ “Regenerative” Rating Tools (= Focus on Nature, Healthy Ecosystem, and Social Issues) } \\
\hline & BREEAM Building & LEED & DGNB & ILFI-LBC & WELL Build & One Planet Living & Cradle2cradle inspired \\
\hline $\begin{array}{l}\text { PLACE, NATURE, } \\
\text { AND ECO-SYSTEM }\end{array}$ & $\begin{array}{l}\text { Environment: } \\
\text { Minimizing the risks to } \\
\text { air and water, soil, and } \\
\text { ecology: Ecological } \\
\text { value retention and } \\
\text { upgrading of the site, } \\
\text { factors for safety and } \\
\text { avoidance of incidents. }\end{array}$ & $\begin{array}{l}\text { Integrative process: } \\
\text { Thoughtful site } \\
\text { selection decisions. } \\
\text { Sustainable Sites: Site } \\
\text { assessment, protect or } \\
\text { restore habitat, soil and } \\
\text { vegetation } \\
\text { guidance, etc. }\end{array}$ & $\begin{array}{l}\text { Environmental quality: } \\
\text { Building life cycle } \\
\text { assessment, local } \\
\text { environmental impact, } \\
\text { sustainable resource } \\
\text { extraction, land use, } \\
\text { biodiversity at the site. }\end{array}$ & $\begin{array}{l}\text { Place: Ecology of place, } \\
\text { urban agriculture, } \\
\text { habitat exchange, } \\
\text { human-scaled living. }\end{array}$ & $\begin{array}{l}\text { Nourishment: Limit } \\
\text { the presence of } \\
\text { unhealthy foods and } \\
\text { encourage better food } \\
\text { culture. }\end{array}$ & $\begin{array}{l}\text { Land and nature: } \\
\text { Protecting and restoring } \\
\text { land for the benefit of } \\
\text { people and wildlife. }\end{array}$ & $\begin{array}{l}\text { C2C principles: } \\
\text { Biodiversity. Everything is } \\
\text { a resource for something } \\
\text { else. "Waste = Food". }\end{array}$ \\
\hline ENERGY & $\begin{array}{l}\text { Energy: Energy } \\
\text { consumption and } \mathrm{CO}_{2} \\
\text { reduction. }\end{array}$ & $\begin{array}{l}\text { Energy and } \\
\text { atmosphere: Optimize } \\
\text { energy performance, } \\
\text { advanced energy } \\
\text { metering, renewable } \\
\text { energy, etc. }\end{array}$ & $\begin{array}{l}\text { Technical Quality: } \\
\text { Sound insulation, } \\
\text { quality of the building } \\
\text { envelope, use and } \\
\text { integration of building } \\
\text { technology, ease of } \\
\text { recovery and } \\
\text { recycling, etc. }\end{array}$ & $\begin{array}{l}\text { Energy: Energy and } \\
\text { carbon reduction, net } \\
\text { positive energy. }\end{array}$ & & $\begin{array}{l}\text { Zero carbon energy: } \\
\text { Making buildings and } \\
\text { manufacturing } \\
\text { energy-efficient and } \\
\text { supplying all energy } \\
\text { with renewables. }\end{array}$ & $\begin{array}{l}\text { C2C principles: Use current } \\
\text { solar income. } \\
\text { Renewable energy and } \\
\text { carbon management: } \\
\text { Products manufactured in a } \\
\text { way that positively impacts } \\
\text { our energy supply, } \\
\text { ecosystem balance, } \\
\text { community, and ultimately } \\
\text { strive to keep carbon in the } \\
\text { soil and earth vegetation } \\
\text { where it belongs. }\end{array}$ \\
\hline CARBON & $\begin{array}{l}\text { Energy: Energy } \\
\text { consumption and } \mathrm{CO}_{2} \\
\text { reduction. }\end{array}$ & & & $\begin{array}{l}\text { Energy: Energy and } \\
\text { carbon reduction, net } \\
\text { positive energy. }\end{array}$ & & Zero carbon energy & $\begin{array}{l}\text { Renewable energy and } \\
\text { carbon management }\end{array}$ \\
\hline WATER & $\begin{array}{l}\text { Water: Consumption } \\
\text { and efficiency. }\end{array}$ & $\begin{array}{l}\text { Water efficiency: Water } \\
\text { use reduction, optimize } \\
\text { process water use, etc. }\end{array}$ & $\begin{array}{l}\text { Environmental quality: } \\
\text { Potable water demand } \\
\text { and wastewater } \\
\text { volume. }\end{array}$ & $\begin{array}{l}\text { Water: Responsible } \\
\text { water use, net positive } \\
\text { water. }\end{array}$ & $\begin{array}{l}\text { Water: High-quality } \\
\text { water and improved } \\
\text { accessibility. }\end{array}$ & $\begin{array}{l}\text { Sustainable water: } \\
\text { Using water efficiently, } \\
\text { protecting local water } \\
\text { resources, and reducing } \\
\text { flooding and droughts. }\end{array}$ & $\begin{array}{l}\text { Water stewardship: } \\
\text { Understanding of (and } \\
\text { responsibility for) water } \\
\text { withdrawals, consumption, } \\
\text { and releases within the local } \\
\text { ecology. }\end{array}$ \\
\hline $\begin{array}{l}\text { MATERIALS AND } \\
\text { RESOURCES }\end{array}$ & $\begin{array}{l}\text { Materials: } \\
\text { Environmental impact } \\
\text { or impact of building } \\
\text { materials used, } \\
\text { including life cycle } \\
\text { impact. }\end{array}$ & $\begin{array}{l}\text { Materials and } \\
\text { resources: Building } \\
\text { life-cycle impact } \\
\text { reduction, building } \\
\text { product disclosure and } \\
\text { optimization, design for } \\
\text { flexibility, construction, } \\
\text { and demolition. }\end{array}$ & & $\begin{array}{l}\text { Materials: Responsible } \\
\text { materials, red list, } \\
\text { responsible sourcing, } \\
\text { living economy } \\
\text { sourcing, net positive } \\
\text { waste. }\end{array}$ & $\begin{array}{l}\text { Materials: Manage } \\
\text { hazardous ingredients } \\
\text { across building } \\
\text { materials, waste, } \\
\text { cleaning products, } \\
\text { outdoor spaces, and } \\
\text { landscaping to reduce } \\
\text { the risk of exposure. }\end{array}$ & $\begin{array}{l}\text { Materials and } \\
\text { products: Using } \\
\text { materials from } \\
\text { sustainable sources and } \\
\text { promoting products } \\
\text { that help people reduce } \\
\text { consumption. }\end{array}$ & $\begin{array}{l}\text { Material health: Products } \\
\text { to be manufactured using } \\
\text { only those materials that } \\
\text { have been optimized and do } \\
\text { not contain any X or Grey } \\
\text { assessed } \\
\text { materials/chemicals. }\end{array}$ \\
\hline
\end{tabular}


Table 2. Cont.

\begin{tabular}{|c|c|c|c|c|c|c|c|}
\hline \multirow{2}{*}{$\begin{array}{l}12 \text { Regenerative } \\
\text { Principles }\end{array}$} & \multicolumn{3}{|c|}{$\begin{array}{c}\text { “Green Building" Rating Tools (= Focus on Energy Efficiency and } \\
\text { Technical Quality) }\end{array}$} & \multicolumn{4}{|c|}{ “Regenerative” Rating Tools (= Focus on Nature, Healthy Ecosystem, and Social Issues) } \\
\hline & BREEAM Building & LEED & DGNB & ILFI-LBC & WELL Build & One Planet Living & Cradle2cradle inspired \\
\hline WASTE & $\begin{array}{l}\text { Waste: Generation of } \\
\text { waste and efficient } \\
\text { avoidance. }\end{array}$ & $\begin{array}{l}\text { Materials and } \\
\text { resources: Building } \\
\text { life-cycle impact } \\
\text { reduction, waste } \\
\text { management. }\end{array}$ & Technical quality & $\begin{array}{l}\text { Materials: Net positive } \\
\text { waste. }\end{array}$ & $\begin{array}{l}\text { Materials: Manage } \\
\text { waste. }\end{array}$ & $\begin{array}{l}\text { Zero waste: Reducing } \\
\text { consumption, reusing, } \\
\text { and recycling to achieve } \\
\text { zero waste and zero } \\
\text { pollution. }\end{array}$ & $\begin{array}{l}\text { C2C principles: Everything } \\
\text { is a resource for something } \\
\text { else. "Waste = Food". } \\
\text { Material reutilization: } \\
\text { Concept of technical } \\
\text { nutrients and biological } \\
\text { nutrients flowing } \\
\text { perpetually in their } \\
\text { respective metabolisms. }\end{array}$ \\
\hline $\begin{array}{l}\text { HEALTH AND } \\
\text { WELL-BEING }\end{array}$ & $\begin{array}{l}\text { Health and comfort: } \\
\text { Indoor and } \\
\text { outdoor-related. }\end{array}$ & $\begin{array}{l}\text { Integrative process: } \\
\text { Including social equity } \\
\text { and public health. } \\
\text { Indoor environmental } \\
\text { quality: Low-emitting } \\
\text { materials, indoor air } \\
\text { quality assessment, } \\
\text { thermal comfort, } \\
\text { interior lighting, } \\
\text { daylight, quality } \\
\text { views, etc. }\end{array}$ & $\begin{array}{l}\text { Sociocultural and } \\
\text { functional quality: } \\
\text { Thermal comfort, } \\
\text { indoor air quality, } \\
\text { acoustic comfort, visual } \\
\text { comfort, user control, } \\
\text { quality of indoor and } \\
\text { outdoor spaces, design } \\
\text { for all, safety and } \\
\text { security. } \\
\text { Technical quality }\end{array}$ & $\begin{array}{l}\text { Health and happiness: } \\
\text { Healthy interior } \\
\text { environment, healthy } \\
\text { interior performance, } \\
\text { access to nature. }\end{array}$ & $\begin{array}{l}\text { Air: Reduce or } \\
\text { minimize sources of } \\
\text { indoor air pollution } \\
\text { Light: Lighting systems } \\
\text { designed to increase } \\
\text { alertness, enhance } \\
\text { experience, and } \\
\text { promote sleep. } \\
\text { Comfort and sound: } \\
\text { Distraction-free, } \\
\text { productive, and } \\
\text { comfortable indoor } \\
\text { environment. } \\
\text { Mind: Optimize } \\
\text { cognitive and emotional } \\
\text { health through design, } \\
\text { technology, and } \\
\text { treatment strategies. }\end{array}$ & $\begin{array}{l}\text { Health and happiness: } \\
\text { Encouraging active, } \\
\text { social, meaningful lives } \\
\text { to promote good health } \\
\text { and well-being. } \\
\text { Local and sustainable } \\
\text { food: Promoting } \\
\text { sustainable humane } \\
\text { farming and healthy } \\
\text { diets high in local, } \\
\text { seasonal, organic food } \\
\text { and vegetable protein. }\end{array}$ & $\begin{array}{l}\text { Material health: Products } \\
\text { to be manufactured using } \\
\text { only those materials that } \\
\text { have been optimized and do } \\
\text { not contain any X or Grey } \\
\text { assessed } \\
\text { materials/chemicals. }\end{array}$ \\
\hline SOCIAL EQUITY & & $\begin{array}{l}\text { Regional priority: } \\
\text { Address geographically } \\
\text { specific environmental, } \\
\text { social equity, and public } \\
\text { health priorities. }\end{array}$ & $\begin{array}{l}\text { Sociocultural and } \\
\text { functional quality }\end{array}$ & $\begin{array}{l}\text { Equity: Universal } \\
\text { access, inclusion. }\end{array}$ & & $\begin{array}{l}\text { Equity and local } \\
\text { economy: Creating safe, } \\
\text { equitable places to live } \\
\text { and work which } \\
\text { support local prosperity } \\
\text { and international fair } \\
\text { trade. }\end{array}$ & $\begin{array}{l}\text { Social fairness: Ensure that } \\
\text { progress is made towards } \\
\text { sustaining business } \\
\text { operations that protect the } \\
\text { value chain and contribute } \\
\text { to all stakeholder interests, } \\
\text { including employees, } \\
\text { customers, community } \\
\text { members, and the } \\
\text { environment. }\end{array}$ \\
\hline
\end{tabular}


Table 2. Cont.

\begin{tabular}{|c|c|c|c|c|c|c|c|}
\hline \multirow{2}{*}{$\begin{array}{l}12 \text { Regenerative } \\
\text { Principles }\end{array}$} & \multicolumn{3}{|c|}{$\begin{array}{c}\text { "Green Building" Rating Tools (= Focus on Energy Efficiency and } \\
\text { Technical Quality) }\end{array}$} & \multicolumn{4}{|c|}{ “Regenerative" Rating Tools (= Focus on Nature, Healthy Ecosystem, and Social Issues) } \\
\hline & BREEAM Building & LEED & DGNB & ILFI-LBC & WELL Build & One Planet Living & Cradle2cradle inspired \\
\hline ECONOMY & $\begin{array}{l}\text { Management: Holistic } \\
\text { management strategies, } \\
\text { operational and process } \\
\text { management. }\end{array}$ & & $\begin{array}{l}\text { Economic quality: Life } \\
\text { cycle cost, flexibility, } \\
\text { and adaptability, } \\
\text { commercial viability. }\end{array}$ & & & $\begin{array}{l}\text { Equity and local } \\
\text { economy: Creating safe, } \\
\text { equitable places to live } \\
\text { and work which } \\
\text { support local prosperity } \\
\text { and international fair } \\
\text { trade. } \\
\text { Local and sustainable } \\
\text { food }\end{array}$ & $\begin{array}{l}\text { C2C principles: Celebrate } \\
\text { diversity. C2C enhances } \\
\text { cultural diversity, } \\
\text { conceptual creativity, and } \\
\text { ecosystem bio-diversity and } \\
\text { well-being. }\end{array}$ \\
\hline $\begin{array}{l}\text { CULTURE AND } \\
\text { COMMUNITY }\end{array}$ & & Regional priority & & $\begin{array}{l}\text { Beauty: Beauty and } \\
\text { biophilia, education and } \\
\text { inspiration. }\end{array}$ & $\begin{array}{l}\text { Community: } \\
\text { Buildings that are } \\
\text { inclusive, accessible, } \\
\text { healthy, and safe, } \\
\text { policies and programs } \\
\text { that support the needs, } \\
\text { health, and wellness of } \\
\text { all individuals and } \\
\text { families. }\end{array}$ & $\begin{array}{l}\text { Culture and } \\
\text { community: Nurturing } \\
\text { local identity and } \\
\text { heritage, empowering } \\
\text { communities, and } \\
\text { promoting a culture of } \\
\text { sustainable living }\end{array}$ & $\begin{array}{l}\text { C2C principles: Celebrate } \\
\text { diversity. }\end{array}$ \\
\hline $\begin{array}{l}\text { ENVIRONMENT } \\
\text { AND MOBILITY }\end{array}$ & $\begin{array}{l}\text { Transport: } \mathrm{CO}_{2} \\
\text { emissions caused by } \\
\text { transport and } \\
\text { location-related factors. }\end{array}$ & $\begin{array}{l}\text { Location and } \\
\text { transportation: } \\
\text { Reduced parking } \\
\text { footprint, no off-street } \\
\text { parking, carshare } \\
\text { parking, electric } \\
\text { vehicles, bicycle } \\
\text { facilities, etc. }\end{array}$ & $\begin{array}{l}\text { Site quality: Local } \\
\text { environment, influence } \\
\text { on the district, transport } \\
\text { access, access to } \\
\text { amenities. }\end{array}$ & & $\begin{array}{l}\text { Movement/fitness: } \\
\text { Encourage the } \\
\text { integration of exercise } \\
\text { and fitness into } \\
\text { everyday life. }\end{array}$ & $\begin{array}{l}\text { Travel and transport: } \\
\text { Reducing the need to } \\
\text { travel, encouraging } \\
\text { walking, cycling, and } \\
\text { low carbon transport. }\end{array}$ & \\
\hline
\end{tabular}


The above-presented comparison exhibits, among other things, that social aspects are considered by all rating tools, though not with the same priorities and weighting. Furthermore, it can be observed that "Green" rating tools include more functional (i.e., functional quality) or overarching goals (i.e., public health priorities), while "regenerative programs" specify more differentiated goals in this regard (i.e., inclusion, social fairness). Other aspects such as "culture and community" or "education and inspiration" are occasionally included, whereby the stated goals focus more on the construction process (e.g., LEED, Integrative process: Improve documentation and process, interdisciplinary analysis) or the focus on innovation and integral planning (i.e., LEED: Integrative process). Conversely, "regenerative" rating systems show a lack of economic goals (LBC, WELL), missing aspects of mobility (LBC), or in the case of the WELL standard, an evaluation of "social justice" only at the community level.

\subsection{Quantitative Data Analysis - Current Status of Regenerative Sustainability Implementation} in the European Built Environment

The percentage of respondents that have followed the application process of materials, technologies, and tools (MTT), which ensure and facilitate regenerative principles in new or renovated buildings, are presented in the graph below (Figure 2). The range of each result addressed the minimum to maximum percentage of implementation of MTT from all construction phases (structure, interior partitions, finishings, etc.). Briefly, the results indicate that $60-65 \%$ (out of 64 respondents) have not used emerging materials or technologies in the construction of new buildings or during the renovation of older ones, while $20-25 \%$ of the respondents have used emerging materials and technologies only between $10-20 \%$ of the overall stages during the construction process. In addition, $52-55 \%$ have not used any tool, whether referring to construction standards or certification systems.

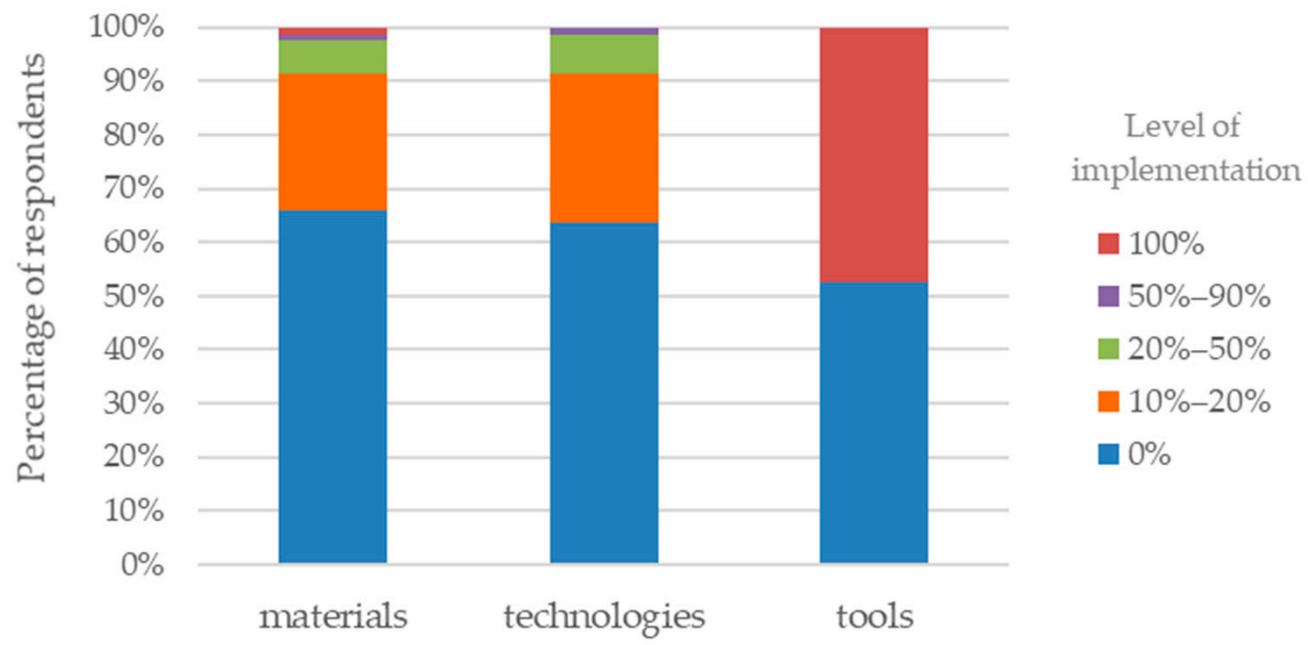

Figure 2. Percentage of respondents $(n=64)$ who have implemented materials, technologies, and tools, that enable regenerative sustainability either for newly built or building renovations constructions.

Research findings on the implementation of the three thematic areas indicate that more than half of the building stock in the European Union does not apply MTT that facilitates regenerative principles in the newly built or building renovations process. Redefining and re-examining the way buildings and districts are constructed is an area for further consideration. Moreover, questions on how the construction industry could adopt MTT solutions, which are based on regenerative sustainability principles, are raised from this survey.

Furthermore, results were obtained from the research regarding the types of buildings to which emerging materials and technologies but also tools that facilitate regenerative building principles have been applied. Figure 3 indicates that for both newly built and building renovations construction, the application of regenerative principles is mostly 
related to commercial, residential, and iconic buildings. Particularly, the aggregate results indicate that in the case of the application of emerging materials in newly built or building renovations construction, a percentage ranging from 25 to $30 \%$ (out of 64 respondents) refers to residential buildings, a percentage ranging from 45 to $55 \%$ refers to commercial buildings, and finally, a percentage of $30-35 \%$ represents iconic buildings. Similarly, in the case of the application of emerging technologies in building renovations or newly built environments, a percentage ranging from 25 to $30 \%$ (out of 64 respondents) refers to residential buildings, a percentage ranging from 45 to $50 \%$ refers to commercial buildings, and finally a percentage of $25 \%$ to iconic buildings.

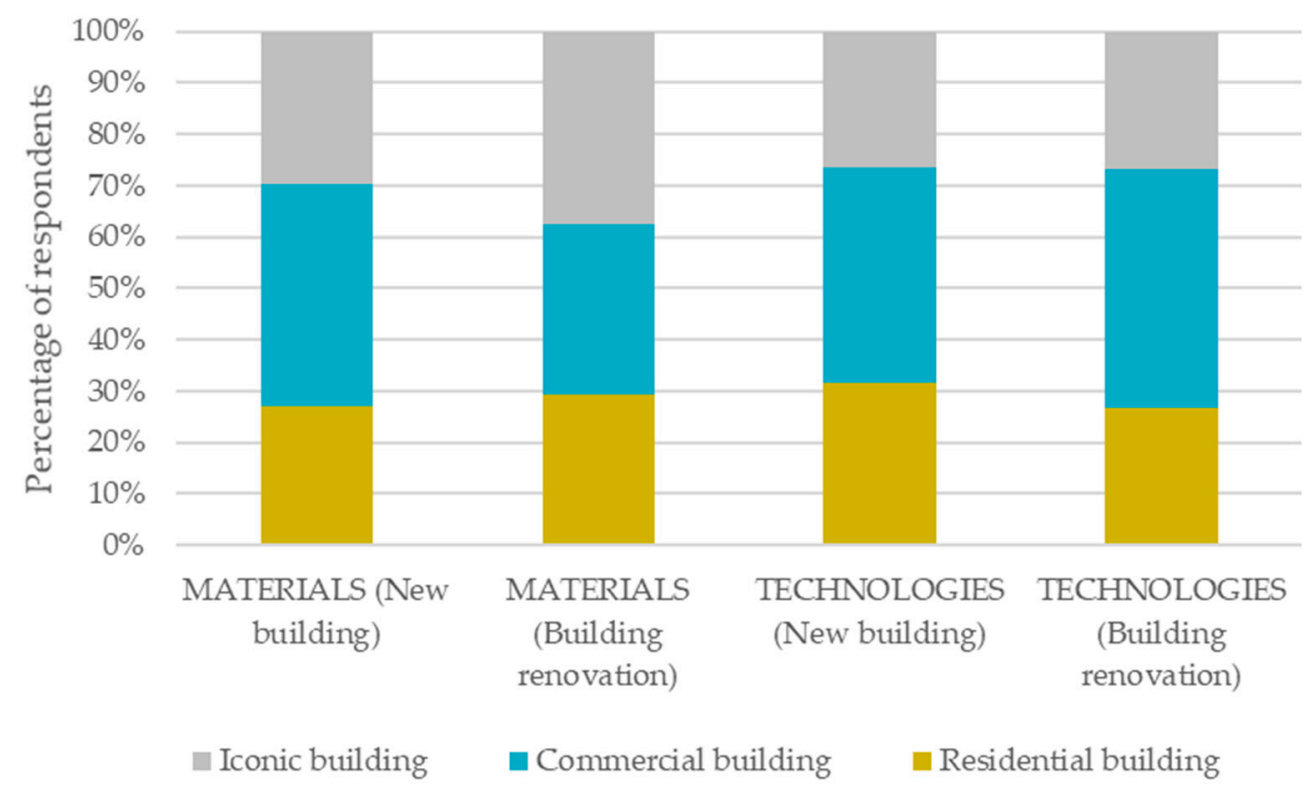

Figure 3. Types of buildings where regenerative materials and technologies were used in newly built or building renovations constructions $(n=64)$.

Based on the undertaken survey, the conclusions regarding the main identified barriers to implementing the emerging materials and technologies, which try to facilitate regenerative new and renovated buildings, have been depicted: Figure 4 demonstrates these results. As it can be observed, four main barriers were identified; the first and most important barrier according to the responses is related to the lack of training, the second and third ones are related to the lack of knowledge and higher cost in implementing emerging materials and technologies, and the fourth barrier identified through the survey is related to the lack of standards and legislation. All the above barriers prevent the further establishment and implementation of emerging materials, technologies, and standards/legislation at the building/district level of development that might allow regenerative sustainability principles to come to the fore.

Built on the results of the questionnaire and its conceivable gaps, a series of conclusions can be drawn which feed the current study and give the impetus for further investigation regarding the types of buildings to which the principles of regenerative sustainability have been applied in Europe. These conclusions open possibilities for expanding regenerative sustainability on neighborhood and urban scales. In addition, conclusions regarding the barriers that prevent their further implementation within the European context are drawn. 


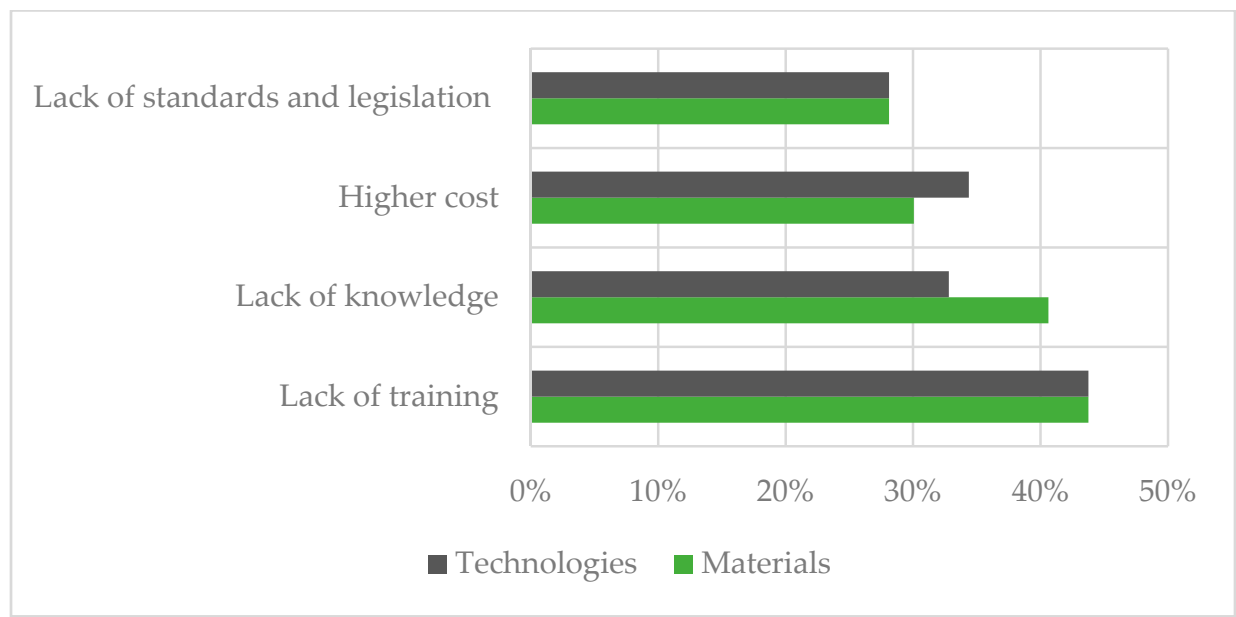

Figure 4. Identified barriers to materials and technologies implementation in newly built and building renovation construction $(n=64)$.

\subsection{Qualitative Data Analysis-Identification of Drivers and Barriers of Regenerative Sustainability}

Table 3 particularly evidences the level of implementation of each regenerative principle during the analyzed case studies. Results show that the twelve regenerative principles were generally implemented at a medium level of implementation. In particular, implementing strategies for effective use and sharing of renewable, restorative, and regenerative energy systems was the principle with the highest level of implementation, as seven case studies highly implemented it in the project.

Using regenerative materials was highly implemented by six of the analyzed case studies and it is the only principle that was implemented at a medium or high level in all the case studies.

In contrast, the least common principles were water management, social equity, and mobility, which had lower levels of implementation.

Furthermore, the interviews also revealed that the owner was the project's main stakeholder who was significantly involved in the decision-making process of implementing the regenerative principles, as it was chosen by eleven out of the thirteen interviewees (80\%). The owner was followed by the architect and investors, which were pointed out by around $50 \%$ of the interviewees.

In contrast to the project managers (23\%), the assessors/auditors (15\%) were the ones that have a lower level of impact on the development of a regenerative building.

Relying on the answers of the interviews' respondents, the regenerative construction approach recounts its basic motivators along with numerous challenges which characterize the process in its different stages. Among the environmental main drivers mentioned by interviewees were an effective use of energy, the use of regenerative materials, and most importantly the building users' well-being. While considering the economic/marketing motivators, the main ones stated were reducing maintenance costs, building users' trust in the developer/investor, and project certification, which directly relates to marketing benefits.

When asked about the challenges experienced during the regenerative construction process, the majority of the buildings' / districts' representatives (10 out of 13) indicated increased construction costs. Further on, 10 out of 13 respondents expressed their concern about the employees' and construction companies' lack of knowledge and experience in regenerative materials and technology. In addition, the challenges faced after the building/district completion are high operation and maintenance costs due to the special treatments of installed systems. 
Table 3. Level of implementation of the twelve regenerative principles in the case studies analyzed.

\begin{tabular}{|c|c|c|c|c|c|c|c|c|c|c|c|c|c|c|c|}
\hline $\begin{array}{l}\text { Case } \\
\text { Study }\end{array}$ & Location & $\begin{array}{l}\text { Type of } \\
\text { Case } \\
\text { Study }\end{array}$ & $\begin{array}{l}\text { Certification } \\
\text { System }^{1}\end{array}$ & $\begin{array}{l}\text { Nature/ } \\
\text { EcoSystem }\end{array}$ & Energy & $\begin{array}{c}\text { Carbon } \\
\text { Emission }\end{array}$ & $\begin{array}{c}\text { Water } \\
\text { Manage- } \\
\text { ment }\end{array}$ & $\begin{array}{l}\text { Regenerative } \\
\text { Materials }\end{array}$ & $\begin{array}{l}\text { Waste } \\
\text { Manage- } \\
\text { ment }\end{array}$ & $\begin{array}{l}\text { Health } \\
\text { and Well- } \\
\text { Being }\end{array}$ & $\begin{array}{l}\text { Social } \\
\text { Equity }\end{array}$ & Economy & $\begin{array}{l}\text { Culture } \\
\text { and Com- } \\
\text { munity }\end{array}$ & $\begin{array}{l}\text { Education } \\
\text { and Inspi- } \\
\text { ration }\end{array}$ & Mobility \\
\hline 1 & WE & Commercial & Green Building (GB) & $\mathrm{M}$ & $\mathrm{H}$ & $\mathrm{M}$ & $\mathrm{H}$ & $\mathrm{H}$ & $\mathrm{M}$ & $\mathrm{H}$ & $\mathrm{H}$ & $\mathrm{H}$ & $\mathrm{M}$ & $\mathrm{M}$ & $\mathrm{H}$ \\
\hline 2 & WE & Commercial & $\begin{array}{c}\text { GB and } \\
\text { Regenerative }\end{array}$ & $\mathrm{H}$ & M & $\mathrm{H}$ & M & $\mathrm{H}$ & M & M & M & M & M & M & M \\
\hline 3 & NE & Commercial & $\begin{array}{c}\text { GB and } \\
\text { Regenerative }\end{array}$ & $\mathrm{L}$ & $\mathrm{L}$ & $\mathrm{H}$ & $\mathrm{L}$ & $\mathrm{H}$ & $\mathrm{L}$ & $\mathrm{L}$ & $\mathrm{L}$ & $\mathrm{H}$ & $\mathrm{L}$ & L & $\mathrm{L}$ \\
\hline 4 & WE & Commercial & Green Building & $\mathrm{H}$ & $\mathrm{H}$ & $\mathrm{H}$ & $\mathrm{H}$ & $\mathrm{H}$ & M & $\mathrm{H}$ & $\mathrm{H}$ & $\mathrm{H}$ & $\mathrm{H}$ & M & $\mathrm{H}$ \\
\hline 5 & $\mathrm{EE}$ & District & Green Building & M & M & $\mathrm{L}$ & M & M & M & $\mathrm{H}$ & M & $\mathrm{L}$ & M & M & M \\
\hline 6 & $\mathrm{EE}$ & Commercial & Regenerative & M & $\mathrm{M}$ & M & M & $\mathrm{M}$ & M & M & $\mathrm{M}$ & M & $\mathrm{M}$ & M & $\mathrm{H}$ \\
\hline 8 & WE & District & Green Building & $\mathrm{H}$ & $\mathrm{H}$ & M & $\mathrm{H}$ & M & M & $\mathrm{H}$ & $\mathrm{L}$ & M & $\mathrm{H}$ & $\mathrm{H}$ & M \\
\hline 9 & SE & Residential & $\begin{array}{c}\text { GB and } \\
\text { Regenerative }\end{array}$ & M & $\mathrm{H}$ & $\mathrm{H}$ & M & $\mathrm{H}$ & M & M & M & M & M & M & M \\
\hline 10 & SE & Residential & Green Building & M & M & M & $\mathrm{H}$ & M & $\mathrm{H}$ & M & $\mathrm{M}$ & M & M & M & $\mathrm{H}$ \\
\hline 11 & SE & Commercial & Regenerative & $\mathrm{H}$ & M & $\mathrm{L}$ & M & $\mathrm{H}$ & M & M & M & M & $\mathrm{H}$ & $\mathrm{H}$ & $\mathrm{L}$ \\
\hline 12 & SE & Residential & Regenerative & M & $\mathrm{H}$ & M & M & $\mathrm{M}$ & $\mathrm{M}$ & M & $\mathrm{L}$ & M & $\mathrm{M}$ & M & $\mathrm{M}$ \\
\hline 13 & SE & Commercial & Green Building & M & $\mathrm{H}$ & $\mathrm{H}$ & $\mathrm{L}$ & $\mathrm{M}$ & $\mathrm{M}$ & $\mathrm{H}$ & M & M & $\mathrm{M}$ & M & $\mathrm{M}$ \\
\hline
\end{tabular}

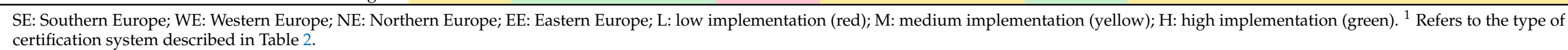


The results also show the high priority given to sustainability certification. Nine out of thirteen interviewees stated that the building certification was the main marketing/sales trigger, another 2 interviewees highly value the economical aspect of the building's certification, and only 2 out of 13 respondents stated that the certification played little or no role at all in the implementation of an innovative project.

Finally, required to provide advice for process facilitation for future projects motivated to implement the regenerative principles, $90 \%$ of the respondents emphasized the need for improved legislation that would match not only the standard construction approach but the regenerative one as well. Tax reduction, improved strategies for public funds and incentives, enhanced public awareness and education schemes, and national financial policies that would stimulate financial institutions to simplify the procedures for issuing loans to such projects would directly inspire and motivate building owners/investors to go for the regenerative construction process instead of the standard one.

Table 4 shows a summary of the identified drivers and barriers that limit or delay the implementation of regenerative sustainability aspects.

Table 4. Summary of identified drivers and barriers of regenerative sustainability.

\begin{tabular}{|c|c|c|c|c|c|}
\hline & No & $\begin{array}{l}\text { Identified Drivers and Barriers of } \\
\text { Regenerative Sustainability }\end{array}$ & $\begin{array}{l}\text { Literature- } \\
\text { Review }\end{array}$ & $\begin{array}{l}\text { Quantitative } \\
\text { Survey }\end{array}$ & $\begin{array}{l}\text { Qualitative } \\
\text { Survey }\end{array}$ \\
\hline \multirow{7}{*}{ BARRIERS } & 1 & $\begin{array}{l}\text { Employees', consultants', and } \\
\text { construction companies' lack of } \\
\text { knowledge and experience. }\end{array}$ & $\checkmark$ & $\checkmark$ & $\checkmark$ \\
\hline & 2 & $\begin{array}{l}\text { Overall stakeholders' resisting culture } \\
\text { and changing/adapting mindset } \\
\text { toward regenerative development. }\end{array}$ & $\checkmark$ & & \\
\hline & 3 & $\begin{array}{l}\text { Lack of standards and legislation, } \\
\text { national and international policies. }\end{array}$ & $\checkmark$ & $\checkmark$ & $\checkmark$ \\
\hline & 4 & $\begin{array}{l}\text { Lack of management and leadership } \\
\text { innovative strategies. }\end{array}$ & $\checkmark$ & & \\
\hline & 5 & Lack of financial incentives. & $\checkmark$ & & $\checkmark$ \\
\hline & 6 & Increased construction cost. & & $\checkmark$ & $\checkmark$ \\
\hline & 7 & $\begin{array}{l}\text { Increased maintenance and operation } \\
\text { cost. }\end{array}$ & & & $\checkmark$ \\
\hline \multirow{7}{*}{ DRIVERS } & 1 & Governmental financial incentives. & $\checkmark$ & & \\
\hline & 2 & Marketing and sales benefits. & $\checkmark$ & & \\
\hline & 3 & $\begin{array}{l}\text { Companies' / investors' image and } \\
\text { competitive market advantage. }\end{array}$ & $\checkmark$ & & $\checkmark$ \\
\hline & 4 & Reduces building lifecycle costs. & $\checkmark$ & & $\checkmark$ \\
\hline & 5 & Effective use of energy. & & & $\checkmark$ \\
\hline & 6 & Buildings' users' well-being. & & & $\checkmark$ \\
\hline & 7 & Receiving building certification. & & & $\checkmark$ \\
\hline
\end{tabular}

\section{Discussion}

Following the previous section which distinguished and identified the principles and goals of regenerative design, this section utilizes the discussion about central influencing factors. The detailed assessment of the regenerative qualities of case studies can serve as a valuable insight to develop and accelerate the scale jumping process, boosting the development of regenerative communities and neighborhoods.

Driven by an in-depth literature review where many authors considered the motivating factors for implementing regenerative principles in a built environment as well as the challenges associated with the entire process, the results of the previously undertaken survey were also analyzed and contrasted with the actual interview results.

Hence, based on the literature, the main barriers accompanying the regenerative construction process include: 1-employees', consultants, and construction companies' lack of knowledge and experience working with regenerative materials and technologies as well 
as with using the available tools that enable such constructions; 2 -overall stakeholders' resisting culture and changing/adapting mindset toward regenerative development ("national", "market", "companies", "business", "energy", etc.); 3-standards and legislation national and international policies; 4-lack of management and leadership innovative strategies; and 5-financial investment barriers. Expressed in more simplified words, the same barriers were identified as the results of the quantitative data analyzed summarized as: 1-lack of employees' knowledge and training on using the regenerative materials and technologies during newly built or renovated construction; 2 -increased construction and maintenance cost because of implementing regenerative principles; and 3-lack of implementation standards and legislation on a national and international level. Finally, these results were reaffirmed through the qualitative data analysis which revealed the main barriers to be: 1 -increased construction costs due to the implementation of regenerative principles; 2-lack of employees' / construction companies' knowledge and experience; 3 -lack of legislation and standards implementation requirements; 4 -increased operation and maintenance costs; and 5-lack of financial incentives.

Furthermore, based on the literature, the identified drivers for implementing the regenerative construction are 1-governmental financial incentives; 2 -marketing and sales benefits; 3-companies' / investors' image and competitive market advantage; and 4 -reduction of building lifecycle costs. In reference to the interviewees' answers, the main motivators for easier implementation of regenerative construction are 1 -effective use of energy; 2-buildings' users' well-being; 3-reducing buildings' maintenance costs; 4-improved developer/investor market image; and 5-receiving building certification.

Aiming to mitigate the barriers and enhance the drivers for implementing the regenerative principles in the built environment, it is highly recommended to extend the level of education and awareness of this process' overall benefits, highlighting them as main drivers for the transition from sustainability to regenerative paradigms and particularly address the role of universities [12]. However, the observed results, both from the survey and the interview case studies, indicate a lack of professional training and knowledge in both handling and processing innovative materials and technologies. This is often due to the reduced or non-existent comprehensive and extensive study programs that refer to regenerative sustainability principles at a university level, as well as being due to the lack of specific disciplines that promote and support regenerative sustainability issues. It is also a result of the reluctance of project managers and contractors to promote and train their staff in regenerative sustainability principles with the prospect of implementing and applying them in real case scenarios. Investment in education, research, and innovation during building and district development is very rare or almost non-existent due to the prioritization of construction managers and contractors, primarily on the "cost and time" and secondly on education and training of their staffs in issues related to innovative materials and technologies.

The lack of standards and legislation that enhance regenerative sustainability was ranked fourth among the barriers derived from the survey analysis, mainly due to regulations, national laws, or political and ideological decisions, which in particular hinder the implementation of regenerative certification tools [5]. This becomes even more difficult when investors consider the financial aspect of the implementation of regenerative certification tools, which is prohibitive in many cases since the goal of such investments is to reduce costs both in the construction and operation phases of buildings or districts. In this case, building upon the research results, a comprehensive review of national and international standards and legislation is encouraged. The simplification of bureaucratic procedures together with available financial incentives would motivate the buildings' stakeholders to choose the regenerative process of construction over the standard one.

The two strands of this research (survey and case studies) revealed a very differentiated picture on the subject of building certification and assessment. On one hand, the survey showed that building certification is a domain of Northern European (NE) and Western European (WE) countries, whereas in Southern European (SE) and Eastern 
European (EE) countries, more local certification systems are used. On the other hand, the case studies show that obtaining or aiming for internationally recognized and highly ranked certification is a key marketing driver for innovative buildings. This means that to implement regenerative aspects in the building sector, certifications are assessed positively and are recognized as a key driver, but they should rather be available in all the countries.

The results also indicate that the different principles of regenerative sustainability are only partially covered across all rating systems. In particular, social impact goals, health, and mobility are hardly considered and evaluated in the same intensity as, e.g., energy, material, or technical quality of the building. Concerning the UN sustainability goals, our results reveal a particular gap. To achieve sustainable development in the sense of the UN sustainability goals on the one hand and a regenerative sustainability approach, on the other hand, special attention must be paid to these aspects. The overarching goals should be to strive for social justice, to narrow the economic gap between countries and individual people, and to take responsibility towards poorer countries and vulnerable groups.

During the past ten years, sustainability certificates for neighborhoods or communities have increasingly entered the market (e.g., BREEAM for Communities, LEED Communities, DGNB certificate for districts). From a regenerative sustainability approach, it is very important to consider buildings and their surrounding environment and infrastructure as a holistic ecosystem. Infrastructure and mobility options, for example, largely determine environmental behavior. Moreover, the mentioned regenerative principles and factors of regenerative sustainability should be considered in a balanced way to avoid undesirable developments and self-regenerating eco-cycles that can restore themselves in the built environment.

\section{Limitations}

However, this research encountered several limitations, namely, the limited number of articles regarding regenerative sustainability of bigger scale projects, or characteristics of the methodology design that impacted the interpretation of the findings due to the small number of regenerative community or neighborhood examples. Taking into account the small number of interviews and questionnaires as well as the limited number of case studies, it was beyond the scope of this research to present a representative statistical sample to generalize results. Nevertheless, the authors could extract valid and interesting insights to identify barriers and drivers in the implementation of regenerative principles in the built environment.

Ultimately, the goal of the research was not to provide a representative study on the implementation of regenerative principles in the built environment nor comprehensive literature and data analysis for building certification tools. Rather, it was to identify the barriers that diminish regenerative sustainability not only in individual projects but also in larger-scale ones, as well as the drivers that promote and encourage developers to go for the application of such principles. However, the identified constraints should be perceived as an excellent opportunity for future research in the broad topic of regenerative sustainability.

\section{Conclusions}

Even though, in general, for many construction industry stakeholders, regenerative sustainability is rather uncommon, the overall interest is consistently increasing, notably because the regenerative principles focus on buildings' users' well-being, social equity, education, inspiration, culture, and community, among all the other environmental data.

The findings of this study indicate that the main barriers that discourage the implementation of regenerative sustainability in large-scale projects are: (1) increased construction costs due to the implementation of regenerative principles; (2) the lack of employees' / construction companies' knowledge and experience; (3) the lack of legislation and standards implementation requirements; (4) increased operation and maintenance costs; and (5) the lack of financial incentives; while the main drivers that motivate the paradigm shift are: (1) the effective use of energy; (2) buildings' users' well-being; (3) reducing build- 
ings' maintenance costs; (4) improved developer/investor market image; and (5) receiving building certification.

Considering the statistical limitations of this study, of literature, or of existing macrolevel case studies to be considered, recommendations for future research may be drawn: (1) identification of the type of education required by consultants, contractors, or other built environment stakeholders to implement the regenerative principles; (2) a review of national and international construction standards and legislation, and a proposal for strengthening the representation and enhancement of regenerative sustainability principles; and (3) identification of the required financial/professional to support built environment stakeholders.

Supplementary Materials: The following are available online at https://www.mdpi.com/article/10 .3390/su13095179/s1, Questionnaire A: Actual State of Sustainable Building Construction; Questionnaire B: Case studies, Semi-structured Interviews.

Author Contributions: Conceptualization, E.H.; methodology, P.V.S. and B.V.R.; writing-original draft preparation, E.H., B.V.R., P.V.S., and O.K.; writing-review and editing, E.H., B.V.R., P.V.S., and O.K. All authors have read and agreed to the published version of the manuscript.

Funding: This research received no external funding, but the APC was funded by the COST Action CA16114 'RESTORE: Rethinking Sustainability towards a Regenerative Economy'. More information can be found at www.eurestore.eu/.

Institutional Review Board Statement: Not applicable.

Informed Consent Statement: Informed consent was obtained from all subjects involved in the study.

Data Availability Statement: The data presented in this study are available on request from the corresponding author. Interview transcripts are not publicly available due to privacy reasons, i.e., they can disclose information that can lead to tracing back to the individuals interviewed.

Acknowledgments: The authors acknowledge interesting aspects that emerged while participating in the COST Action CA16114 "RESTORE: Rethinking Sustainability towards a Regenerative Economy". We want to thank and acknowledge the respondents and interviewees for the information provided, which was necessary to develop this study. Further, the authors are grateful to three anonymous reviewers, whose suggestions greatly improved the paper.

Conflicts of Interest: The authors declare no conflict of interest.

\section{References}

1. UN Environment and International Energy Agency. Towards a zero-emission, efficient, and resilient buildings and construction sector. In Global Status Report; UN Environment and International Energy Agency, 2017; Available online: https:/ / www.worldgbc. org/news-media/global-status-report-2017 (accessed on 1 May 2021).

2. Brown, M.; Haselsteiner, E.; Apro, D.; Kopeva, D.; Luca, E.; Pulkkinen, K.-L.; Rizvanolli, B.V. (Eds.) Sustainability, Restorative to Regenerative. An Exploration in Progressing a Paradigm Shift in Built Environment Thinking, from Sustainability to Restorative Sustainability and on to Regenerative Sustainability; COST Action CA16114 RESTORE: Wien, Austria, 2018; Available online: https:/ / www.eurestore.eu/wp-content/uploads/2018/05/RESTORE_booklet_print_END.pdf (accessed on 1 May 2021).

3. Cole, R.J. Regenerative design and development: Current theory and practice. Build. Res. Inf. 2012, 40, 1-6. [CrossRef]

4. Reed, B. Shifting from sustainability to regeneration. Build. Res. Inf. 2007, 35, 674-680. [CrossRef]

5. Forsberg, M.; de Souza, C. Implementing regenerative standards in politically green nordic social welfare states: Can Sweden adopt the living building challenge? Sustainability 2021, 13, 738. [CrossRef]

6. $\quad$ Brown, M. Futurestorative: Working Towards a New Sustainability; Riba Publishing: London, UK, 2016; ISBN 978-1-85946-630-8.

7. Lyle, J.T. Regenerative Design for Sustainable Development; John Wiley \& Sons: Hoboken, NJ, USA, 1996; ISBN 978-0-471-17843-9.

8. Pomponi, F.; Moncaster, A. Circular economy for the built environment: A research framework. J. Clean. Prod. 2017, 143, 710-718. [CrossRef]

9. Opoku, A. Biodiversity and the built environment: Implications for the sustainable development goals (SDGs). Resour. Conserv. Recycl. 2019, 141, 1-7. [CrossRef]

10. Heisel, F.; Rau-Oberhuber, S. Calculation and evaluation of circularity indicators for the built environment using the case studies of UMAR and Madaster. J. Clean. Prod. 2020, 243, 118482. [CrossRef]

11. Hankinson, M.; Breytenbach, A. Barriers that impact on the implementation of sustainable design. In Proceedings of the Cumulus, Helsinki, Finland, 2012; Available online: https:/ / www.semanticscholar.org/paper/Barriers-that-impact-on-theimplementation-of-Hankinson-Breytenbach/302614ffac4ed8cf73b570b0c13ae5351a37a60b (accessed on 1 May 2021). 
12. Sonetti, G.; Brown, M.; Naboni, E. About the triggering of UN sustainable development goals and regenerative sustainability in higher education. Sustainability 2019, 11, 254. [CrossRef]

13. Thomas, K.; Hardy, R.D.; Lazrus, H.; Mendez, M.; Orlove, B.; Rivera-Collazo, I.; Roberts, J.T.; Rockman, M.; Warner, B.P.; Winthrop, R. Explaining differential vulnerability to climate change: A social science review. Wiley Interdiscip. Rev. Clim. Chang. 2019, 10, 13. [CrossRef]

14. Heckenberg, D.; Johnston, I. Climate change, gender and natural disasters: Social differences and environment-related victimisation. In Climate Change from a Criminological Perspective; White, R., Ed.; Springer: New York, NY, USA, 2012; pp. 149-171. ISBN 978-1-4614-3640-9.

15. Du Plessis, C. Towards a regenerative paradigm for the built environment. Build. Res. Inf. 2012, 40, 7-22. [CrossRef]

16. Cepeliauskaite, G.; Stasiskiene, Z. The framework of the principles of sustainable urban ecosystems development and functioning. Sustainality 2020, 12, 720. [CrossRef]

17. Naboni, E.; Natanian, J.; Brizzi, G.; Florio, P.; Chokhachian, A.; Galanos, T.; Rastogi, P. A digital workflow to quantify regenerative urban design in the context of a changing climate. Renew. Sustain. Energy Rev. 2019, 113, 109255. [CrossRef]

18. Mang, P.; Reed, B. Designing from place: A regenerative framework and methodology. Build. Res. Inf. 2012, 40, 23-38. [CrossRef]

19. Reed, R.; Bilos, A.; Wilkinson, S.J.; Schulte, K.-W. An International Comparison of International Sustainable Building Tools. In Proceedings of the 16th Annual European Real Estate Society Conference, Stockholm, Sweden, 2009; Available online: https:/ /ideas.repec.org/p/arz/wpaper/eres2009_331.html (accessed on 1 May 2021).

20. GXN. Statens Byggeforskningsinstitut Guide to Sustainable Building Certifications; SBI: Mumbai, India, 2018; ISBN 978-87-563-1881-5.

21. Berardi, U. Sustainability assessment in the construction sector: Rating systems and rated buildings. Sustain. Dev. 2011, 20, 411-424. [CrossRef]

22. Shan, M.; Hwang, B.-G. Green building rating systems: Global reviews of practices and research efforts. Sustain. Cities Soc. 2018, 39, 172-180. [CrossRef]

23. Atanda, J.O.; Öztürk, A. Social criteria of sustainable development in relation to green building assessment tools. Environ. Dev. Sustain. 2018, 22, 61-87. [CrossRef]

24. Doan, D.T.; GhaffarianHoseini, A.; Naismith, N.; Zhang, T.; GhaffarianHoseini, A.; Tookey, J. A critical comparison of green building rating systems. Build. Environ. 2017, 123, 243-260. [CrossRef]

25. Morseletto, P. Restorative and regenerative: Exploring the concepts in the circular economy. J. Ind. Ecol. 2020, 24, 763-773. [CrossRef]

26. Hart, J.; Adams, K.; Giesekam, J.; Tingley, D.D.; Pomponi, F. Barriers and drivers in a circular economy: The case of the built environment. Procedia CIRP 2019, 80, 619-624. [CrossRef]

27. Ametepey, O.; Aigbavboa, C.; Ansah, K. Barriers to successful implementation of sustainable construction in the ghanaian construction industry. Procedia Manuf. 2015, 3, 1682-1689. [CrossRef]

28. Sovacool, B.K.; Griffiths, S. The cultural barriers to a low-carbon future: A review of six mobility and energy transitions across 28 countries. Renew. Sustain. Energy Rev. 2020, 119, 109569. [CrossRef]

29. Stephenson, J.; Barton, B.; Carrington, G.; Gnoth, D.; Lawson, R.; Thorsnes, P. Energy cultures: A framework for understanding energy behaviours. Energy Policy 2010, 38, 6120-6129. [CrossRef]

30. Stephenson, J. Sustainability cultures and energy research: An actor-centred interpretation of cultural theory. Energy Res. Soc. Sci. 2018, 44, 242-249. [CrossRef]

31. Loh, S.; Foth, M.; Caldwell, G.A.; Garcia-Hansen, V.; Thomson, M. A more-than-human perspective on understanding the performance of the built environment. Arch. Sci. Rev. 2020, 63, 372-383. [CrossRef]

32. Shan, M.; Hwang, B.-G.; Zhu, L. A global review of sustainable construction project financing: Policies, practices, and research efforts. Sustainability 2017, 9, 2347. [CrossRef]

33. Mosannenzadeh, F.; Di Nucci, M.R.; Vettorato, D. Identifying and prioritizing barriers to implementation of smart energy city projects in Europe: An empirical approach. Energy Policy 2017, 105, 191-201. [CrossRef]

34. Agyekum, K.; Adinyira, E.; Baiden, B.; Ampratwum, G.; Duah, D. Barriers to the adoption of green certification of buildings. J. Eng. Des. Technol. 2019, 17, 1035-1055. [CrossRef]

35. Darko, A.; Chan, A.P.C. Review of barriers to green building adoption. Sustain. Dev. 2016, 25, 167-179. [CrossRef]

36. Darko, A.; Zhang, C.; Chan, A.P. Drivers for green building: A review of empirical studies. Habitat Int. 2017, 60, 34-49. [CrossRef]

37. Giorgi, S.; Lavagna, M.; Campioli, A. Circular economy and regeneration of building stock: Policy improvements, stakeholder networking and life cycle tools. In Seismic Behavior of Steel Storage Pallet Racking Systems; Metzler, J.B., Ed.; Springer: Berlin/Heidelberg, Germany, 2019; pp. 291-301.

38. Talamo, C.; Lavagna, M.; Monticelli, C.; Atta, N.; Giorgi, S.; Viscuso, S. Re-netta. Re-manufacturing networks for tertiary architectures. In Seismic Behavior of Steel Storage Pallet Racking Systems; Metzler, J.B., Ed.; Springer: Berlin/Heidelberg, Germany, 2019; Volume 38, pp. 303-314.

39. Bolger, K.; Doyon, A. Circular cities: Exploring local government strategies to facilitate a circular economy. Eur. Plan. Stud. 2019, 27, 2184-2205. [CrossRef]

40. Hossain, U.; Ng, S.T.; Antwi-Afari, P.; Amor, B. Circular economy and the construction industry: Existing trends, challenges and prospective framework for sustainable construction. Renew. Sustain. Energy Rev. 2020, 130, 109948. [CrossRef] 
41. Ranta, V.; Aarikka-Stenroos, L.; Ritala, P.; Mäkinen, S.J. Exploring institutional drivers and barriers of the circular economy: A cross-regional comparison of China, the US, and Europe. Resour. Conserv. Recycl. 2018, 135, 70-82. [CrossRef]

42. Cole, R.J. Transitioning from green to regenerative design. Build. Res. Inf. 2012, 40, 39-53. [CrossRef]

43. Craft, W.; Ding, L.; Prasad, D.; Partridge, L.; Else, D. Development of a regenerative design model for building retrofits. Procedia Eng. 2017, 180, 658-668. [CrossRef]

44. Robinson, J.; Cole, R.J. Theoretical underpinnings of regenerative sustainability. Build. Res. Inf. 2015, 43, 133-143. [CrossRef]

45. Villoria Sáez, P.; Kontovourkis, O.; Rizvanolli, B.V.; Del Río Merino, M. Construction. In Regenerative Construction and Operation. Bridging the Gap between Design and Construction, Following a Life Cycle Approach Consisting of Practical Approaches for Procurement, Construction, Operation and Future Life; RESTORE Working Group Three Report: Restorative Sustainability; COST Action CA16114 RESTORE: Wien, Austria, 2019; pp. 59-88.

46. Patton, M.Q. Qualitative Research E Evaluation Methods: Integrating Theory and Practice, 4th ed.; SAGE Publications Inc.: Thousand Oaks, CA, USA, 2015; ISBN 978-1-4129-7212-3.

47. Tenhouten, W.D. Site sampling and snowball sampling-methodology for accessing hard-to-reach populations. Bull. Sociol. Methodol. 2017, 134, 58-61. [CrossRef]

48. Sáez, P.V.; Merino, M.D.R.; Porras-Amores, C.; Astorqui, J.S.C.; Pericot, N.G. Analysis of best practices to prevent and manage the waste generated in building rehabilitation works. Sustainality 2019, 11, 2796. [CrossRef]

49. Guyatt, G.H.; Townsend, M.; Berman, L.B.; Keller, J.L. A comparison of Likert and visual analogue scales for measuring change in function. J. Chronic Dis. 1987, 40, 1129-1133. [CrossRef]

50. Sklair, L. The transnational capitalist class and contemporary architecture in globalizing cities. Int. J. Urban Reg. Res. 2005, 29, 485-500. [CrossRef]

51. UNSD. Methodology. Available online: https://unstats.un.org/unsd/methodology/m49/ (accessed on 13 April 2021).

52. Cole, R.J.; Oliver, A.; Robinson, J. Regenerative design, socio-ecological systems and co-evolution. Build. Res. Inf. 2013, 41, 237-247. [CrossRef]

53. Mang, P.; Reed, B. Regenerative development and design. In Sustainable Built Environments; Metzler, J.B., Ed.; Springer: Berlin/Heidelberg, Germany, 2020; pp. 115-141.

54. Larrick, S. A living systems model for assessing and promoting the sustainability of communities. In Proceedings of the Annual Conference of the Community Development Society, Athens, GA, USA, 27 June 1997. 